\title{
Joseph Flipper
}

Between Apocalypse and Eschaton. Minneapolis: Fortress Press, 2015. Pp. viii + 224.

$\mathrm{Pb}, \$ 44$.

The Jesuit Henri de Lubac is almost universally recognized as one of the preeminent twentieth-century theologians, influencing thinkers and ideas in diverse and sometimes opposed schools of thought. For both Catholic and ecumenical theology, his numerous contributions-in Patristic exegesis, the relationship between nature and grace, and ecclesiology—have rightly been hailed as transformative for academy and church alike. The same kind of recognition, however, has not typically been extended to his work on eschatology or politics, particularly in the English-speaking world. This is especially true insofar as de Lubac is frequently read as a Communio thinker whose opposition to political and liberation theologies began after the Second Vatican Council and continued throughout his later works. Joseph Flipper's important new book seeks to foster broader recognition and conversation about these issues through a deep engagement with de Lubac himself and with the broader thought-world out of and into which the great French Jesuit's thought emerged.

That thought-world, according to Flipper, focuses on the issue of history and its fulfillment (2). History thus constitutes Flipper's key theme in elaborating de Lubac's work, which he analyzes along with an impressive historical treatment of de Lubac's context and interlocutors. Particularly helpful for scholars of the period is his treatment of Henri-Marie Féret, O.P., and Gaston Fessard, S.J., neglected figures whose work Flipper puts into constructive dialogue with de Lubac's. Both were deeply concerned with the apocalypse and its relationship to history and the present-day life of the church. Flipper reads Féret as advocating a kind of immanent eschatology in which "the Christian must hope for a transformation of the world in history, and not just in eternity" (66). Fessard's approach, by comparison, hews much closer to de Lubac's by focusing on the limitations of historical progress with respect to eschatology and placing hope in God's future. The present-day reader is struck, in Flipper's analysis, with how contemporary their approaches sound, particularly inasmuch as the differences between their positions foreshadowed later theological divisions. Along with Flipper's discussion of the more well-known Jean Daniélou, S.J., his analysis of these thinkers helps contextualize de Lubac more fully with respect to the issues Flipper is engaging.

Flipper sets himself the challenging task of reading de Lubac eschatologically through all the major areas of his oeuvre mentioned above. He thus critiques the tendency to separate de Lubac's work on nature and grace from his other writings. He particularly integrates into this holistic reading of de 
Lubac a discussion of his late work on Joachim of Fiore, yet to be translated into English. Central to this reading is a vision of sacrament as "the core of de Lubac's various theological engagements" (209). Flipper reads "sacrament" as a historical reality that at the same time points to eschatological fulfilment, a point Flipper thinks is particularly important with respect to ecclesiology. The church, on Flipper's reading, must be eschatological so that there is no "objectification of the visible church, confusion of human and divine action, or 'fetishization' of the assembly" (240).

It is on this issue of the church and its eschatological fulfilment that Flipper posits a "deep conflict" in de Lubac, "on the relationship between social conditions and the kingdom of God" (247). This became particularly important with respect to theologies, such as that of the Dominican Edward Schillebeeckx, claiming that "the entire world is in historical process towards an eschatological salvation," which the church makes visibly explicit (249). This issue, on which de Lubac was deeply critical, constituted one of the key fault-lines in post-Vatican II Catholicism between Communio and Concilium approaches to theology and church, one whose effects resound today. Concilium, the older of the two theological journals that give name to these schools of thought, tends toward viewing the theological renewal surrounding Vatican II, and indeed the council itself, as a continuing project, particularly with respect to political issues; Communio, founded by de Lubac, Joseph Ratzinger, and others, as a kind of counterpoint, tends toward viewing the theological renewal at Vatican II as a necessary corrective to what went before, but not necessarily with the same continuing or expansive nature. Flipper here critiques de Lubac for failure to be fully consistent between his ecclesiology and understanding of sacramentality. In other words, Flipper argues that de Lubac's attempt to divorce temporal progress from eschatology, and thus in some sense the political from the church, is not true to his own foundational insights about the intrinsic desire for grace within created nature. Flipper thus praises de Lubac's theology of nature and grace for opening the way to other approaches, such as those of Schillebeeckx and the liberation theologians, whose priorities he did not share. Flipper's analysis concludes with an affirmation of de Lubac's vision, particularly with respect to sacred and secular, specifically in their anticipation of latter developments with respect to the secular as well as in their opening up to the mystical.

Flipper's book performs a great service for students of de Lubac and la nouvelle théologie by pursuing a thorough and accurate reading of a complex, important, and largely neglected issue in de Lubac's thought. The satisfaction derived from this exploration, however, raises further questions that understandably were not within Flipper's purview, even as they seem to drive the 
work. While Flipper's reading effectively critiques readings of de Lubac that might underplay the eschatological dimensions of the church in favor of its current configuration, it in turn underplays somewhat the real tensions between de Lubac's later work, particularly the book on Joachim, and other theologies-notably political and liberation theologies-that were emerging at the time. Flipper alludes to these issues and gives a measured critique of de Lubac on them, described above - the effect, however, is to leave the reader seeking a fuller elaboration of how affirmation of de Lubac's overall project can be squared with support of theological approaches he himself came to find deeply problematic. Given that Flipper has put de Lubac's work to use in support of an approach that seems to affirm political and liberation theologies, it would be helpful to have a fuller elaboration of some of these challenges. A further analysis of de Lubac's "pre-history" on these issues as found in the series of essays on theological and political matters before and during World War II might also have shown more fully the contours of de Lubac's ideas on these issues, particularly with reference to the writings of Féret and Fessard from the same period. The excellent treatment Flipper gives de Lubac's writings thus invites from him a further, more systematic treatment of these matters and the relevance of de Lubac's work to them.

\section{Daniel Rober}

Fordham University

rober@fordham.edu

DOI 10.1163/22141332-00303008-24 